\title{
Child Trafficking in the Case of Wolaita Zone, Southern Nation Nationalities and Peoples' Region, Ethiopia
}

\author{
Yishak Gecho, Asrat Worku \\ Department of Rural Development and Agricultural Extension, College of Agriculture, Wolaita Sodo University, Wolaita Sodo, Ethiopia \\ Email address: \\ yishakgecho@yahoo.com (Y. Gecho), asish268@gmail.com (A. Worku) \\ To cite this article: \\ Yishak Gecho, Asrat Worku. Child Trafficking in the Case of Wolaita Zone, Southern Nation Nationalities and Peoples' Region, Ethiopia. \\ Humanities and Social Sciences. Vol. 6, No. 2, 2018, pp. 38-53. doi: 10.11648/j.hss.20180602.11
}

Received: March 12, 2018; Accepted: April 20, 2018; Published: May 15, 2018

\begin{abstract}
This study was conducted in Woliata Zone of Southern Ethiopia where the practice of child trafficking is one of the most challenging problems and happing at alarming rate. Its aim was to assess prevalenceof child trafficking; to identify and investigate the causes and consequences of child trafficking in the study area and finally to analysis demographic and socio-economic characteristics of trafficked children and parents of the victims. For the purpose of this study primary data were collected from 90 trafficked children in three administrative towns and 87 parents of the victim in four rural woredas (districts) of the zone. In addition, key informant interview and focus group discussion were used to supplement the survey with qualitative information. Secondary data were also collected from various relevant sources. Descriptive statistics was applied to characterize the survey children's and parents' social, economic and demographic factors. The finding of the study revealed that the basic livelihood assets like farm size is very small and is not in position to enable families of trafficked children to generate adequate income and access to food in sustainable way. Majority of the survey parents (75.9\%) owned no oxen during the survey period. Themean age of trafficked children was 13.2 years old with minimum age was 8 years. About $57.8 \%$ trafficked children reported that food access for their family is very bad. Friends/peer pressure, brokers and families are the major agents of child trafficking in the study area. The large proportion (92.4\%) of the survey children reported that poor economic condition of their family is a major factors which facilitate the processes. Labour exploitation is a common practice among trafficked children. Majority of the interviewed children reported that their life situation after trafficking is worst. Out of total survey children about $76.6 \%$ dropped education. The data from both the survey and key informant interview depicted that trafficked children are facing a serious negative consequences like punishment, unfair payment, hunger, poor health (sickness) and labour exploitation, sleeping under ditch/homelessness, begging, rape, psychological, mental and physical abuse. Many children had no knowledge about the negative consequences of the trafficking before exposure. The results of this study therefore suggest that government and other concerned bodies to give considerable attention in designing relevant strategies to overcome the existing problem of child trafficking.
\end{abstract}

Keywords: Child Trafficking, Cause, Consequences, Woliata Zone

\section{Introduction}

\subsection{Background of the Study}

Child trafficking is a modern form of slavery and it involves exploitation of human beings in the most intolerable way by deceiving and taking them from their home and family [1]. It is a crime that deprives children's human rights and freedoms, increases health risks, fuels growing networks of organized crime, and can sustain levels of poverty and impede development in certain areas. The impacts of child trafficking are devastating. Victims may suffer physical and emotional abuse, rape, threats against self and family, and even death. But the devastation also extends beyond individual victims; child trafficking undermines the health, safety, and security of all nations it touches [2].

Children are an important group in any society. They have only one chance of a childhood. They deserve to be protected from different kinds of abuse. Children require special care and protection because of their mental and physical immaturity. They need to be brought up in an environment capable of providing care and affection [3]. Because, child 
abuse is one of the major social problems facing children throughout the world $[4,5]$. However, it varies from place to place and the culture and nature of the society [6]. Children in Ethiopia have rights which are ratified and adapted in the international and national level such as United Nations Convention on the Right of Children (1990), African Charter on the Rights and Welfare of the Child (1990), Constitution of the Federal Democratic Republic of Ethiopia (1995). Although they possess all rights which are recognized by international and national bodies, they are prone to different types of child abuse - physical, sexual, neglect and psychological/emotional [7-10].

Child trafficking is a serious crime that many governments, non-governmental organizations (NGOs) and community-based organizations (CBOs) around the world are trying to address [11]. Child trafficking involves multiple forms of exploitation, and therefore has been described as modern slavery. It involves forced labour such as prostitution and other forms of sexual exploitation, debt bondage, coercion or the threat of violence against the victim, as well as physical and mental abuse and related violations of fundamental human rights. Trafficking is a global problem and the victims have issues of poverty and desperation in common.

Ethiopia is a source country for children subjected to trafficking in persons, specifically conditions of forced labor and forced prostitution. Girls from Ethiopia's rural areas are forced into domestic servitude and commercial sexual exploitation, while boys are subjected to forced labor in traditional weaving, agriculture, herding, and street vending. Small numbers of Ethiopian girls are forced into domestic servitude outside Ethiopia, primarily in Djibouti and Sudan, while Ethiopian boys are subjected to forced labor in Djibouti as shop assistants and errand boys [1].

In response to the above problems, the Ethiopian Government recently ratified ILO's worst forms of children labor convention (number 182) thereby committing itself to take immediate and effective measures to secure prohibition and elimination of worst forms of child labor including trafficking of children. But, by issuing laws alone, trafficking cannot be prevented and due to the illegal nature of the act, it is not an easy task to identify and bring the traffickers to justice [12].

Child trafficking is a challenge phenomenon for many developing world. Despite existing UN Convention on the Rights of the Child (1989), the practice still continues to exist on a massive scale, sometimes in appalling conditions, particularly in this world. International Labor Organization (ILO), estimates that there are around 211 million children aged between 5-14 working in hazardous and intolerable occupations in worldwide because of child trafficking [13]. Moreover, in Ethiopia, children are becoming exposed to through child trafficking. It also indicates that most of them engaged in Agriculture sector and unorganized sectors [1].

According to ANPPCAN's (African Network on the Prevention and Protection of Child Abuse and Neglect) study conducted in 2008 in Ethiopia, Kenya, Tanzania and Uganda, child trafficking is widespread and rampant in the four countries. The study exposed key issues surrounding child trafficking in East African region, confirming that the problem is real [14].

Convention No.182 states that tackling the worst form of child trafficking should be prioritized in every country and immediate action should be taken as a matter of human rights, saving lives and building a nation's future. There is a three phase plan to address child trafficking and child labor. The first thing in this regard is to conduct a research or survey to detail the extent of and depth of the problem. The second phase entails taking measures to prevent the employment of children in harmful working condition. The third phase is the elimination of child labor [15].

Trafficked children engage in various activities such as commercial sex, domestic work and agriculture, all of which expose them to risks. Children aged between 13 and 17 are the most preferred by traffickers because of their cheap labour potential. Girls are most preferred because they can be used as domestic servants, commercial sex workers and perhaps are more submissive [15].

With the exception of some survey studies made by the United Nations' agencies like International Labor Organization (ILO), United Nations Children's Fund (UNICEF) and International Organization for Migration (IOM), and some reports indicated by Ministry of Labor and Social Affairs (MOLSA) and Child Labor Survey Reports by the Central Statistics Authority, the problem of child trafficking in the country has not been properly researched and documented. So, the need for an investigation into the problem is all the more essential and timely [1].

More strongly than other areas, child trafficking is a serious problems in Wolaita zone. Traffickers use various means and routes to transport children to different places, especially to urban areas. According to Wolaita zone women and child affair office report, out of 1,690,461 total population living in wolaita zone, almost half of population, estimated around 812,096 comprises children with 15 years old age. Among them about 50,350 children are living with either no or single parents. These children are easily vulnerable or exposed to traffickers. In 2012 the local government of the zone in Sodo town controlled about 1256 trafficked children who were transported from rural to urban areas. In the same year the local authority returned these children to their parents home [16].

The recent study conducted in Sodo town on street children indicated that about 1136 children living in street of Sodo town. Among them, the average age of the girls was 11 while average age for boys was 12 years old. It was indicated by this study that certain proportion of these street children were the victims of child trafficking. As the study reveals the number of street children is increasing from time to time at substantial rate [16]. At the current time the situation is beyond the capacity to manage by governmental and nongovernmental organizations, who are engaged on fighting the violence against child life. Many negative consequences have been seen on children due to illegal trafficking. However, 
little effort has been done to protect the prevailing situations. Therefore, conducting empirical research on child trafficking can play great role to overcome the deep-rooted problem existing in the zone through indentifying the main causes and consequences of child trafficking.

Similarly, as mentioned earlier at present time child trafficking is a serious problem in Wolaita zone. However, research work on child trafficking in study area is very limited. The existing situations of trafficked children are not assessed in detail. The factors that determine child trafficking are not well identified. The socio-economic and psychological consequences of trafficked children is not deeply investigated. This study therefore aims to assess prevalence/trends of child trafficking in Wolaita Zone; and identify factors that expose children to traffickers in the zone and to assess the consequences of child trafficking in the study area.

\section{Research Methodology}

\subsection{Description of the Study Area}

The study area, Wolaita Zone, is one of 13 Zones in southern Nation Nationalities and Peoples Regional State (SNNPRS). It is located at $390 \mathrm{~km}$ to southwest from the capital city of the country, Addis Ababa along the main road that passes through Shashamane to Arbaminch. Now, newly constructed Sodo-Hosana asphalted road reduced $60 \mathrm{~km}$ distance to Addis Ababa, which is following main road that passes through Hosanna to Arbaminch. The Zone is roughly located between $6.4^{\circ}-7.1^{\circ} \mathrm{N}$ and $37.4^{\circ}-38.2^{\circ} \mathrm{E}$, latitude and longitude respectively. It covers a total area of $4,511 \mathrm{~km}^{2}$ and is composed of 12 administrative weredas and 3 registered towns. The Zone shares borders with KembataTembaro and Hadiya Zones in the North, Oromia administrative region in the North East, Sidama Zone in the East, Gamogofa Zone in the south, and Dawuro Zone in the South West.

According to Central Statistical Agency report of 2010, total number of population of the area is about 1,581,650. Out of this, male are 781,068 (49.4\%); while female comprises about 800,582 (50.6\%). About 1,364,943 (86.3\%) people live in rural area while only 216,707 (13.7\%) people in urban area. Population density of the area is estimated at 385 per square kilometer [17]

The Zone is classified into three agro-ecological zones, among them large proportion is Wayna-Dega (mid-altitude) which is about $56 \%$ of the area; the rest $35 \%$ and $9 \%$ is described as Kola (low altitude), and Dega (high altitude) respectively. The estimated average annual rainfall is 801 to $1600 \mathrm{~mm}$. The rainfall in the Zone is characterized by bimodal distribution pattern and the main rainy season (Maher) is between Junes and continues up to end of September and Belg is from late February to late March/early April. The annual average temperature of the zone is $21.86^{\circ} \mathrm{C}$. The altitude of the zone ranges from 501 to 3000 meter above sea level [18].

According to Wolaita zone finance and economic development department, out of the total area of the zone 258,198 ha $(57.2 \%)$ is cultivated, 48,116 ha $(10.7 \%)$ grazing, $86,429(19.2 \%)$ forest and bush, and the rest 14,911 ha (3.3\%) occupied by others (nonproductive land, home seated, and water body) [18]. Land shortage is an acute problem in the study area due to population growth. The maximum and minimum land holdings of households in the zone are 0.5 and 0.13 hectare respectively. If the population growth continues at the same rate, many people will be landless after certain years. Those who own a very small farm size will take feeding the majority. Therefore, dependency will become a serious problem.

Agriculture is the main economic base of the zone though it is mainly subsistence, and is characterized by low productivity. The principal agricultural activities in the study area are crop production and livestock rearing, which depends on rainfall. Subsistence mixed farming is the dominant farming system in the study area. A significant proportion of rural households also undertake non-farm and off-farm activities outside agriculture and that make an important contribution to cash income, particularly for resource poor households.

\subsection{Sampling Procedure}

Various approaches were employed to select study unit for this study. In the first stage, five rural woredas and three urban areas were selected purposively because of high prevalence/existence of child trafficking. Among the towns in the zone Sodo, Areka and Bodit were selected where the route of child trafficking widely practiced. Five rural woredas (KindoDidaye, Humbo, S/Zuria, DugunaFango and Boloso Bombe) were selected based on prior information about child trafficking. In the case of studying child trafficking taking sample frame or getting the number of total population of trafficked children is impossible or challenging. Moreover, drawing a sufficiently sized random sample of trafficking victims and traffickers would be extraordinarily difficult and expensive. Even if the researchers tried to get adequate number of sample to represent the situation. Based on careful consideration of the level of survey reporting required and the resources allotted for planning and implementing the survey, a sample size of close to 180 respondents were selected for inclusion in the study. A purposive sampling method were used to select 90 trafficked children (including returnees) and 87 parents of the trafficked children. Both male and female victim children were included within age of $8-17$. The trafficked children were selected based on the information from women and child affairs office, kebele administration (urban and rural areas). The parents selection also were done in discussion with woreda offices of women and child affairs. It was planned to use proxy traffickers through using snowball methods, but couldn't done. Key informants like Gender officers both at woreda and Zonal level, police officers, delegates from bus station and Zonal prosecutorswere included to get important information. 


\subsection{Methods of Data Collection}

\subsubsection{Types and Sources of Data Collection}

Both quantitative and qualitative methods were employed to collect primary data for this study.Primary data were collected from trafficked children (children return to their parents' home,street children who come to urban area by child trafficker, those children living under the care of authority in Sodo Town, children selling lottery b/c of child trafficking, children engaged in shoe making by trafficker, child bar and children working on beam balance, etc), parents, government officials working on violence against child trafficking, etc.

Secondary data was collected from governmental offices especially from zonal and woreda women and child affair offices, cases from court and police office. Past reports on child trafficking and other secondary data available in the form of policy statement, child right and research reports were collected to supplement primary data. Moreover, secondary data from media reports, case studies and NGOs working on violence against child trafficking. Obtaining case study information from court and police office were also obtained.

\subsubsection{Methods of Data Collection}

The researchers applied various methods of data collection to triangulate the survey result. Data collection methods such as structured and semi-structured questionnaire, deep interview, case study, focus group discussion and observation were applied. Interview schedule were used to collect data from trafficked children and parents of trafficked children regarding to the main causes and consequences of child trafficking. Observation also was used as one of data collection tools to see labor exploitation of trafficked children. Case study were conducted on trafficked children ) from survey areas. Focus group discussion was conducted with trafficked children (4 focus group discussions) and parents( 4 focus group discussions). Key informants interview with women's and child affair officers at different administration levels (at zone, woreda and kebele level), court,police officers, trafficker/proxy traffickers, bus station and NGOs working on violence against child trafficking. Researchers was planned to interview and collect data from employers and brokers/child traffickers, but it was not successful due to respondents lack of confidence. The questionnaires were pre-tested and necessary modifications was incorporated before the final administration.

\subsection{Methods of Data Analysis}

Descriptive statistical methods were used to analyze the data collected from respondents.Both quantitative and qualitative statistical methods were applied. Quantitative categorical types of data were analyzed using percentage, frequency. While quantitative continuous types of variables were analyzed using mean and standard deviation. Besides, qualitative data were described, compared, summarizedand interpreted in detail.Statistical softwareof SPSS 20 was applied for data processing.

\section{Result and Discussion}

This part presents the survey results based on the data from trafficked children and parents' of the victims. First section, deals with demographic characteristics of both trafficked children and the parents of the victims. Second section discusses about the socio-economic situations of the respondents. Factors exposing children to trafficking and consequences ofthe trafficking are discussed in section three and four, respectively. Finally, section five demonstrates awareness of parents and children towards child trafficking and their understanding about the existing legal condition to protect child trafficking.

\subsection{Demographic Characteristics of the Respondents}

\subsubsection{Sex}

The data for this study generated from 90 trafficked children and 87 parents of trafficked children. Both male and female were involved in this study. However,the proportion of male is more than female respondents in both trafficked children and parents of the victim. The survey result indicates that out of the total trafficked children, about $71 \%$ and $28.9 \%$ were male and female respectively. Similarly, in terms of sex, the proportion of male parents of trafficked children was almost similar to that of the survey children (Table 1). The results of this study implies that child trafficking is not sex neutral; it affects both sexes equally.

Table 1. Sex of the respondents.

\begin{tabular}{lllll}
\hline \multirow{3}{*}{ Sex } & \multicolumn{3}{l}{ Respondent category } \\
\cline { 2 - 5 } & \multicolumn{2}{l}{ Trafficked children } & Parents of trafficked children \\
\cline { 2 - 5 } & Frequency & Percent & Frequency & Percent \\
\hline Male & 64 & 71.1 & 63 & 72.4 \\
Female & 26 & 28.9 & 24 & 27.6 \\
Total & 90 & 100.0 & 87 & 100.0 \\
\hline
\end{tabular}

Source: Survey result, 2016/17

\subsubsection{Age of the Respondents}

As the survey data indicates, large percentage $(52.1 \%)$ of trafficked children were between the ages of 8 and 13, followed by the age group 14 to $15(33.3 \%)$, and fewer number children trafficked between the ages of 16 and 17 $(14.4 \%)$ (Table 2$)$. It is reported that mean age of trafficked children was 13.2 years old with minimum age was 8 years. In terms of age, similar result also reported by parents of trafficked children in that the average age of trafficked children was 12.51 years. From parents response, majority $(83 \%)$ of children fall on the hands trafficker between $8-15$ years old (Table 2). The process make the children drop school and expose them to different challenges at the early age. Key informant interview and office data also strengthen this fact in that most of the children expose to trafficker at the age of 12-14 years. 
Table 2. Age of trafficked children.

\begin{tabular}{lllll}
\hline \multirow{2}{*}{$\begin{array}{l}\text { Age } \\
\text { category }\end{array}$} & \multicolumn{4}{l}{ Respondents category } \\
\cline { 2 - 5 } & \multicolumn{2}{l}{ Trafficked Children response } & \multicolumn{2}{l}{ Parents' response } \\
\cline { 2 - 5 } & Frequency & Percent & Frequency & Percent \\
\hline $8-10$ & 13 & 14.5 & 20 & 23 \\
$11-15$ & 64 & 71 & 53 & 60.9 \\
$16-17$ & 13 & 14.5 & 4 & 4.6 \\
Total & 90 & 100 & 87 & 100 \\
Mean & 13.2 & & 12.51 & \\
STD & 2.11 & & 2.21 & \\
Max & 17 & 17 & \\
Min & 8 & & 8 & \\
\hline
\end{tabular}

Source: Survey result, 2016/17

\subsubsection{Family Size}

Family size is considered as one of main factors in enhancing child trafficking in the study area. Households with large family size and endowed with limited access to productive resource can't afforded basic necessities life (like food, clothes, education, health care) to their children. In absence such kind material needs, children do not want to stay with their family. This pave a way for trafficker to deceive immature children from local area.According to the study, family size was very high in the study area. The mean value of family size reported by trafficked children and parents of the victims was 6.8 and 8.4, respectively (Table 3 ). This average is higher than the national average of 4.8 [19] and it indicates that the study area is heavily populated.

Table 3. Trafficked children's and parents response on family size.

\begin{tabular}{|c|c|c|c|c|c|}
\hline \multirow{3}{*}{ Family size } & \multicolumn{5}{|c|}{ Respondent category } \\
\hline & \multicolumn{2}{|c|}{ Child response } & \multicolumn{3}{|c|}{ Parents response } \\
\hline & Frequency & Percent & $\begin{array}{l}\text { Family } \\
\text { size }\end{array}$ & Frequency & Percent \\
\hline $3-5$ & 20 & 22.2 & $3-6$ & 16 & 18.4 \\
\hline $6-7$ & 47 & 52.2 & $7-10$ & 61 & 70.1 \\
\hline 8-19 & 23 & 25.6 & $11-21$ & 10 & 11.5 \\
\hline Total & 90 & 100 & Total & 87 & 100 \\
\hline Mean & 6.8 & & Mean & 8.42 & \\
\hline STD & 2.0 & & STD & 2.7 & \\
\hline Max & 19 & & Max & 21 & \\
\hline Min & 3 & & Min & 3 & \\
\hline $\begin{array}{l}\text { Dependency } \\
\text { ratio }\end{array}$ & 1.29 & & & & \\
\hline
\end{tabular}

Dependency ratio is also very high in the study area. Household with high dependency ratio will face shortage of labour to undertake activities that bring benefit to household and also it creates competition on limited resources. In this regard dependency ratio represents the proportion of dependent household members (household members aged less than 15 years and those older than 65 years) to that of economically active age group (15-65). The overall mean dependency ratio of the sampled respondents was 1.29 i.e. the proportion of economically non-active persons to economically active person within the family in the sample area found to be $129 \%$. In other words every 100 economically active person of the sample population expected to support with basic necessities for 129 economically non-active (dependent members) including $\mathrm{him} /$ herself. This implies that one active labor force in a households on average shoulder almost about one economically inactive family member (Table 3).

\subsubsection{Level of Education}

\section{Education level of trafficked children}

The survey result revealed that majority of children dropped their education from first cycle education due to various reasons. Among the trafficked children, 4 children did not attend school completely. Majority (58.8\%)of them attend first cycle education and the rest, accounted for about $36.6 \%$ attained second cycle (Table 4). Average value of education for trafficked children were 4.1 grade.

Table 4. Trafficked children's response on their level of education.

\begin{tabular}{lll}
\hline Level of education & Frequency & Percent \\
\hline Not attended school & 4 & 4.4 \\
First cycle (1-4 grade) & 53 & 58.8 \\
Second cycle (5-8) & 33 & 36.6 \\
Total & 90 & 100 \\
Mean & 4.1 & \\
STD & 1.9 & \\
Max & 8 & \\
Min & 0 & \\
\hline
\end{tabular}

Source: Survey result, 2016/17

Education level of parents' of trafficked children

Source: Survey result, 2016/17

Table 5. Educational level of parents' of trafficked children (responses from both survey parents' and trafficked children).

\begin{tabular}{|c|c|c|c|c|c|c|}
\hline \multirow{3}{*}{ Level of education } & \multirow{2}{*}{\multicolumn{2}{|c|}{ Parents' response }} & \multicolumn{4}{|c|}{ Trafficked children's response } \\
\hline & & & \multicolumn{2}{|c|}{ Father } & \multicolumn{2}{|l|}{ Mother } \\
\hline & Frequency & Percent & Frequency & Percent & Frequency & Percent \\
\hline Illiterate & 36 & 41.4 & 32 & 41.5 & 61 & 79.2 \\
\hline Primary school (1-6) & 36 & 41.4 & 19 & 24.7 & 14 & 18.2 \\
\hline Junior (7-8) & 7 & 6 & 13 & 16.9 & 2 & 2.6 \\
\hline High school (9-12) & 8 & 9.2 & 13 & 16.9 & 0 & \\
\hline Total & 87 & 100 & 77 & 100 & 77 & \\
\hline STD & 3.48 & & 3.92 & & 2.00 & \\
\hline Max & 12 & & 12 & & 7 & \\
\hline Min & 0 & & 00 & & 00 & \\
\hline
\end{tabular}

Source: Survey result, 2016/17 
Education is an important variable that can determines the parent's ability to communicate, acquire information about the legal issue and other important thing in their community related child trafficking. According to the study the mean years of school attained by parents of trafficked children was found to be 3.31 with standard deviation of 3.48. Regarding to the level of education, the responses from both sides, surveyed parents and trafficked children, confirmed that more proportion of parents were illiterate. Out of the total surveyed households about 41.4\% didn't attend any formal education (Table 5). Almost similar result reported by trafficked children about the educational level of their parents in which large proportion of their mothers and fathers were illiterate (Table 5). This study has great implication that due to illiteracy parents may not follow up the information passes through mass media and another sources which teaching about the negative consequences of child trafficking.

\subsection{Socio-Economic Characteristics of the Respondents}

\subsubsection{Farm size of the Victims' Families}

Access to food and income directly depend on availability and size of the land in the study area. Farm land is one of the basic assets for agrarian community on which livelihood of the most people depends. It is very serious issue in Wolaita Zone, as almost all the available farmland is already cultivated and there is no possibility for further expansion. As reported by parents of the victim, the average land size was 0.296 ha with standard deviation of 0.266 hectare. As reported by both parents and trafficked children, the large proportion of households owned $\leq 0.25$ hectare of land, which constitute about $41.1 \%$ of trafficked children and $73.6 \%$ of parents of the victims' response (Table 6). This is very small and not enable households to obtain adequate amount of product to fulfill food and income requirement of their family. Most probably, this is the reasons for majority of children who are exposed to traffickers in the study area either by deceiving or cheating.

Table 6. Trafficked children and parent responses on farm size.

\begin{tabular}{lllll}
\hline & \multicolumn{2}{l}{ Parent's responses } & \multicolumn{2}{l}{ Trafficked children } \\
\hline Farm size & Frequency & Percent & Frequency & Percent \\
\hline$\leq 0.25$ & 64 & 73.6 & 37 & 41.1 \\
$0.26-0.50$ & 16 & 18.4 & 33 & 36.7 \\
$0.51-1.00$ & 5 & 5.7 & 9 & 10 \\
$\geq 1.01$ & 2 & 2.3 & 14 & 15.5 \\
Total & 87 & & 90 & \\
Mean & .296 & & .51 & \\
STD & .266 & & .37 & \\
Max & 2 & 2 & \\
Min & .03 & & .03 & \\
\hline
\end{tabular}

Source: Survey result, 2016/17

\subsubsection{Livestock Ownership of the Victims' Families}

Livestock is one of the basic assets for farmers in the study area. It benefits rural households in different ways, namely, as a source income, milk, egg, meat, drought power and means of transport. In most cases, rural households often use livestock as measure of wealth i.e. plays significant role as store of wealth (saving). The kinds of livestock reared in the study area include cattle, sheep, goats, donkeys, mule, and poultry. As Table 7 shows, among livestock, cattle, goat and sheep reared by large number of respondents. Particularly, small ruminants and chicken are the first to be sold during a serious cash and food shortage season. They act as immediate cash for emergency events. According to the survey result, the average number of livestock in TLU for the interviewed parents was 1.52 per households with standard deviation of 1.43. As survey data shows in Table 7 , about $10.5 \%$ of parents of the victims reported that they have no livestock during the survey time.

Table 7. Parents response on livestock ownership in Tropical Livestock unit.

\begin{tabular}{lll}
\hline Number of TLU & Frequency & Percent \\
\hline 0 & 9 & 10.5 \\
$0.013-1: 00$ & 27 & 31 \\
$1: 01-2: 00$ & 29 & 33.3 \\
$2: 01-3: 00$ & 13 & 14.9 \\
$>3$ & 9 & 10.5 \\
Mean & 1.52 & \\
STD & 1.43 & \\
Min & 0 & \\
Max & 5 & \\
\hline
\end{tabular}

Source: Survey result, 2016/17

\section{Oxen ownership of the victims' family}

Oxen ownership plays a very vital role for farming community, in study area, to conduct agricultural activities. Particularly, oxen are an important factor of production as it is a primary source of power for land cultivation. Most commonly in study area a household who has a pair of oxen is considered as independent and self reliant. $\mathrm{B} / \mathrm{c}$ this helps a household to assure timely plowing and secure better production. However, the lack of oxen, the basic source of livelihood in rural areas, is a severe problem facing large number of households in the study area.

The research result indicates that the mean value of oxen ownership of the interviewed households was 0.24 ranges from 0 to 3 with standard deviation of 0.31 . As can be seen from the Table 8 , about $75.9 \%$ of respondents owned no oxen during the survey period. A significant number of interviewed parents, estimated about $21.8 \%$ of all interviewed households owned only 1 ox, which could not enable them prepare farm land alone.

Table 8. Parents response on oxen ownership.

\begin{tabular}{lll}
\hline Number of oxen & Frequency & Percent \\
\hline 0 (no oxen) & 66 & 75.9 \\
1 & 19 & 21.8 \\
2 & 1 & 1.1 \\
3 & 1 & 1.1 \\
Own oxen & 21 & 24.1 \\
Total & 87 & 100 \\
\hline
\end{tabular}

Source: Survey result, 2016/17 


\subsubsection{Income Source Victims' Families}

Even if, agricultural land is declining from time to time, a significant part of the households still engaged in farming activities in the study area. The survey result indicated that about $40 \%$ and $37 \%$ of families of trafficked children and parents of the victim respectively engaged in agriculture (crop and animal production) as their livelihood strategies. The remaining, large parts of the families $(63 \%)$ combine agriculture with other activities like non-farm and off-farm. The non-farm and off-farm activities help farmers to fill income gap that agriculture unable to do. In this regard, about $30 \%$ of the families of trafficked children derived their livelihood from farming plus non-farming activities. Various types of non-farm activities pursued by respondents include petty trade, handcrafts, weaving/spinning, sale of local drink, rent of pack animal and remittance. On the other hand, proportionally about $17.2 \%$ of the families of trafficked children drive their livelihood by combining farming with off-farming activities, while a significant numbers of the households generate their income from farming + nonfarming + off-farming, which constituted about $16.7 \%$ of the trafficked children who were involved in the study (Table 9).

The finding of this study depicts that large number of families of trafficked children engaged in non-farm and offfarm activities in addition to agriculture. Many scholars also confirm this truth in that non-agricultural employment (non/off-farm activities) arises from the survival strategies of rural households unable to obtain employment or selfemployment in agriculture [20-22]. According to them, it is a last resort rather than an attractive alternative livelihood. The study by Berry [23] and Muib [21] also strengthen this fact in that poor farmers who increasingly engage in off-farm activities may rather be doing so as a long-term adaptation to stress, shocks and poverty - these farmers are trying simply to survive in a poorer, riskier world, rather than to improve livelihoods and invest in production. This finding also suggest that off-farm activities are survival mechanisms pursued mainly by the poor groups but not viewed as an opportunity that farmers engage in as a choice, that means it is a pushing factor in absence of alternative livelihood activities.

Table 9. Income source of families of trafficked children.

\begin{tabular}{|c|c|c|c|c|}
\hline \multirow{3}{*}{ Income source } & \multicolumn{4}{|c|}{ Respondent category } \\
\hline & \multicolumn{2}{|c|}{ Child Response } & \multicolumn{2}{|c|}{ Parent Response } \\
\hline & Frequency & Percent & Frequency & Percent \\
\hline Farming (crop and animal production) & 36 & 40.0 & 32 & 36.8 \\
\hline Non-farming & 1 & 1.1 & 7 & 8.0 \\
\hline Off-farming & 3 & 3.3 & 3 & 3.4 \\
\hline Farming and non-farming & 27 & 30.0 & 22 & 25.3 \\
\hline Farming and off-farming & 8 & 8.9 & 15 & 17.2 \\
\hline Total & 90 & 100.0 & 87 & 100 \\
\hline
\end{tabular}

Source: Survey result, 2016/17

Wealth status of trafficked children's family: Regarding to wealth status, majority of the parents' of trafficked children perceived that their wealth status is poor, which reported by $64.4 \%$ of parents of trafficked children. Similarly, about $34.4 \%$ of them responded as their wealth status is relatively medium compared with local community (Table 10).

Table 10. Parents response on comparison of their Wealth status with local community.

\begin{tabular}{lll}
\hline Wealth status & Frequency & Percent \\
\hline Poor & 56 & 64.4 \\
Medium & 30 & 34.5 \\
Better off & 1 & 1.1 \\
Total & 87 & 100.0 \\
\hline
\end{tabular}

Source: Survey result, 2016/17

\subsubsection{Food Access of Trafficked Children's Families}

Household food access and availability is one of the main factors of child trafficking. Most of time children expose to trafficking in search of daily survival especially for the sake of having food. According to survey data, about $57.8 \%$ trafficked children reported that food access for their family is bad. Even, there is time in that the victims' family jumps meal, which constitute more than half $(54.4 \%)$ of the families of trafficked children. More proportion (64.4\%) of the families of trafficked children get food two times per day (Table 11).

Table 11. Children's response on food access of their family.

\begin{tabular}{llll}
\hline Variable & $\begin{array}{l}\text { Response } \\
\text { category }\end{array}$ & Frequency & Percent \\
\hline \multirow{4}{*}{ Victim's family access to food } & V good & 10 & 11.1 \\
& Good & 25 & 27.8 \\
& Bad & 52 & 57.8 \\
& Worst & 3 & 3.3 \\
& Total & 90 & 100.0 \\
Victim family jumps meal & Yes & 49 & 54.4 \\
& No & 41 & 45.6 \\
& Total & 90 & 100.0 \\
Frequency of having food per & one time & 4 & 4.4 \\
day & two times & 58 & 64.4 \\
& three times & 28 & 31.1 \\
& Total & 90 & 100 \\
\hline
\end{tabular}

Source: Survey result, 2016/17

\subsection{Agents and Factors of Child Trafficking}

\subsubsection{Child Trafficking Agents/Bodies in the Study Area}

As the survey result indicates, various bodies expose children for trafficking. The major agents of child trafficking 
in the study area are friends/peer pressure, brokers, relatives, families, and neighbors. As shown in Table 12, friends play a key role in exposing children for traffickers, in which $41.1 \%$ trafficked children reported as they were cheated from local area by their friends. Following this, brokers and family are the next major agents of child trafficking. Many children in Wolaita zone are moved between relatives for various reasons ranging from cultural practices of traditional fostering. However, these traditional fostering practices have sometimes led to abuse of fostered children, who are then trafficked. Some of the victims informed that they were initiated by more than one bodies. This considers concerned bodies to take actions in order to overcome the problem (prevailing issue) by providing awareness creation training for local community, setting appropriate prevention and controlling mechanisms at office level.

Similarly, the woreda and zonal offices also reported the principal agents that expose children to traffickers. The common trafficking agents mentioned by the offices are broker, peer pressure, and family. According to the evidence from woreda and zonal offices, most of time children trafficked by brokers, who are from the same village or community. Brokers are not getting appropriate punishment $\mathrm{b} / \mathrm{c}$ the process disabled by traditional judge/mediators. People lie by saying they are relatives or sister or brother. Peer pressure also plays a key role in child trafficking in that most children follow those friends who went town, they looks friends' wearing style, clothes and shoes, experience urban life. Then, other children eager/initiate to go town to buy/wear clothes like those friends already experienced urban life. Family enforcement is another factor which facilitate child trafficking. Family send children somewhere expecting to get some amount money, purchasing clothes and shoe. When sending they say children are going to town to live with sister, brother or relatives. As reported by zonal police office, fruit and butter traders are also another agents. They traffic children in secrete manner. They seem as they are conducting real trade but their main task is child trafficking. The most common destinations of trafficked children are Hawasa, Addis Ababa, Adadma, Shashimene, Shakisho, Ziway, Hosana, Sodo and other towns throughout Ethiopia.

Table 12. Children and parents' response on the bodies/agents exposing children for trafficking in local area.

\begin{tabular}{|c|c|c|c|c|c|c|}
\hline & Children Response & & & Parents Response & & \\
\hline Trafficking body & Frequency $(\mathrm{N}=90)$ & Percent & Rank & Frequency $(\mathbf{N}=87)$ & Percent & Rank \\
\hline Family & 26 & 28.9 & 3 & 14 & 16.1 & 3 \\
\hline Friends & 37 & 41.1 & 1 & 49 & 56.3 & 1 \\
\hline Neighbors & 7 & 7.8 & 5 & 6 & 6.9 & 5 \\
\hline Brokers & 27 & 30 & 2 & 27 & 31 & 2 \\
\hline Self-initiation & & & & 7 & 8.1 & 4 \\
\hline
\end{tabular}

Source: Survey result, 2016/17

\subsubsection{Factors Exposing Children for Trafficking}

The root causes of child trafficking in the study area are many and varied. Children become part of trafficking chain because of various reasons that are either push or pull factors. As indicated in Table 13, trafficked children mentioned several factors which lead them to child trafficking. According to the finding, the large proportion (57.8\%) of the survey children reported that poor economic condition of their family is a major factors which facilitate the processes. Poverty is responsible for driving children out of their rural communities to migrate to urban slums and force the children out on to streets, it also makes them prone to be fallen in the hands of cruel child traffickers. Following this, factors like children's curiosity to support their family, peer pressure, hoping/expecting to live better life in town, observing their friends change in wearing new clothes and putting shoes, absence (death) of their parents, searching for employment, family pressure, bad living condition in rural area are also play great role in enhancing child trafficking. False promises of good employment and education opportunities, misconception of the city life are some of the pull factors that make children victims of the traffickers. Children are easily exposed to abuses due to the fact that they are less assertive and less able to claim their rights than adults, and they can be made to work longer hours with less food, accommodation and payment. These are some of the demand factors that play roles in the growth of child trafficking according to the reports. On the other word, the demand for inexpensive labour rose the interest on children. Traditional arrangements of child fostering and placement can leave children vulnerable to exploitative conditions and to greater risks of being trafficked.

Similarly, parents of trafficked children also reported that the major factors which initiate or facilitate exposure of children for traffickers. As they mentioned, poor economic condition of the family is indicated as a prime factors. This condition hinder the family not to send their children to school, supply food, purchase clothes and exercise book. Large proportion of the interviewed parents, accounted for about $74.7 \%$ of the respondents reported that poor economic condition not enable them to assist children to stay with them at home. Some other factors mentioned by the survey parents are cheating/giving false hope as there is better life in the town or urban area, peer pressure, chronic hunger. These play great role in exposing children to traffickers (Table 14). The information from key informants and focus group discussion also presented similar idea on the major factors exposing children to trafficking in the study area. 
Table 13. Children response on factors exposing them to traffickers.

\begin{tabular}{llll}
\hline Response & Frequency (N=90) & Percent & Rank \\
\hline 1. To change life situation from poor living condition & 27 & 30 & 3 \\
2. To support their family & 10 & 11.1 & 5 \\
3. Families' poor economic condition force them to trafficker & 52 & 57.8 & 1 \\
4. Very small land size & 4 & 4.4 & 10 \\
5. Peer-pressure & 28 & 31.1 & 2 \\
6. Conflict with their family & 3 & 3.3 & 13 \\
7. To buy clothes & 5 & 5.6 & 9 \\
8. Expecting life in the town is interesting/attractive & 8 & 8.9 & 7 \\
9. Searching for employment & 4 & 4.4 & 10 \\
10. Deceiving as there is good life in town & 10 & 11.1 & 5 \\
11. Family forced to go town/family enforcement & 4 & 4.4 & 10 \\
12. Bad life in rural area & 2 & 2.2 & 14 \\
13. Death of parents (mother and/or father) & 6 & 6.6 & 8 \\
14. Lack of information for negative effect of child trafficking & 1 & 1.1 & 15 \\
\hline
\end{tabular}

Source: Survey result, 2016/17

Table 14. Parents' response on factors exposing children for trafficking.

\begin{tabular}{lll}
\hline Factors & Frequency (N=87) & Percent \\
\hline 1. Families' poor economic condition not allow to send school \& fulfill basic needs (no clothes) & 65 & 74.7 \\
2. Broker cheat by giving hope as there is better life in town/urban area & 5 & 5.7 \\
3. Peer pressure/they follow others' who went to somewhere (change in clothes, etc) & 12 & 13.8 \\
4. Chronic hunger & 11 & 12.6 \\
5. Shortage of farm land & 1 & 1.1 \\
6. Self interest & 1 & 1.1 \\
\hline
\end{tabular}

Source: Survey result, 2016/2017

\subsubsection{Parents' Knowledge/Information for Trafficked Children}

The children were asked to check whether their families/parents have information on their trafficking. Regarding to this, large proportion $(62.2 \%)$ of the children reported that their parents have no information while they were exposed to trafficker. In contrary to this, some children $(37.8 \%)$ reported that their parents had knowledge at the time of their exposure. This support the aforementioned result that some children are exposed to trafficker by their families. Families give children for their relatives living in town expecting fostering or sending school, but most times relatives mishandle the children. Then, the situation force them to escape from primarily hosting bodies and this create conducive situation for traffickers. According to the survey data, some parents encourage children to go other place, which is accounted for about $37.8 \%$ interviewed children report (Table 15).

Table 15. Children response on their family'sknowledge on child trafficking.

\begin{tabular}{llll}
\hline Variable & Response category & Frequency & Percent \\
\hline & Yes & 34 & 37.8 \\
Did your parents know that you left to new area & No & 56 & 62.2 \\
& Total & 90 & 10 \\
Did your family encourage you to go to other place? & Yes & 34 & 37.8 \\
& No & 56 & 62.2 \\
\hline
\end{tabular}

Source: Survey result, 2016/17

\subsubsection{Methods/Means Used by Trafficker to Traffic Children from Local Area}

Traffickers use different mechanism to traffic children from local area. The most common ones are contacting children through friends in local market, contacting through neighbors at village, broker cheat/ deceive by giving money, broker gives false hope/promise to buy clothes and send school. The remaining respondents reported that they have no information about the methods used by traffickers to get children from local area. In this regard, out of total surveyed parents of the victims, about $34.5 \%$ reported that they know the route and means of transportation the trafficker use. On the other hand, majority of the respondents $(65.5 \%)$ of the parents of victims reported that they have totally no information/knowledge about the route and methods of the transportation (Table 16). According to police office report, trafficker use different directions to escape children from their control and transport children on foot rather than using bus.

New strategy traffickers use: Brokers order the children to walk a long distance through village. They not allow them to use bus thinking that traffic police and bus station security not allows young children to transport from one area to the other. i.e. 
children use a village tour to travel up to certain distance to take bus station and then brokers met children and put in one class. All activities and works that trafficked children to do were ordered by brokers

Table 16. Parents' knowledge on methods and routes used by traffickers to get children from local area.

\begin{tabular}{lll}
\hline Means/routes & $\begin{array}{l}\text { Frequency } \\
\text { (N=87) }\end{array}$ & Percent \\
\hline $\begin{array}{l}\text { Trafficker contact children through their } \\
\text { friends at local market }\end{array}$ & 23 & 26.4 \\
$\begin{array}{l}\text { Brokers contact children through friend and } \\
\text { neighbors at local area }\end{array}$ & 13 & 14.9 \\
$\begin{array}{l}\text { Broker Deceive by giving money } \\
\text { Broker deceive by giving false } \\
\text { promise/hope to buy clothes \& send school }\end{array}$ & 2 & 2.3 \\
$\begin{array}{l}\text { Parents give child to traffickers by } \\
\text { themselves }\end{array}$ & 2 & 17.5 \\
$\begin{array}{l}\text { No information/knowledge at all } \\
\text { Parents knowledge on means of } \\
\text { transportation traffickers use }\end{array}$ & 32 & 2.3 \\
Yes & & 36.8 \\
$\begin{array}{l}\text { No } \\
\text { Total }\end{array}$ & 30 & \\
\hline
\end{tabular}

Source: Survey result, 2016/17

\subsubsection{Working and Payment Condition of Trafficked Children}

Children mentioned various kind of works which performed by them. These are cooking food, washing clothes, cleaning house, selling lottery, working at restaurant, etc. Children engaged in work under age. In addition to this, parents also mentioned different kind of works performed by children (Table 17). The data from focus group discuss and key informants interview also indicated similar activities which performed by the children. Some the activities mentioned by them are keeping cattle, selling lottery, shoe shining, selling mobile card, beam balance (body weighting), engage in farming activities, female work at private home as maids According to the report, labor exploitation is the most challenging problem among the trafficked children.

Those children who are not getting payment for work were asked the reasons for no payment. They forwarded various reasons for this like given with only hope to buy clothes, providing food, sending school. According to the response of the trafficked children, they face bad treatment from their employers. About $65.5 \%$ of the children were ill-treated by employers. Even majority of the children had no freedom to play with their friends at free time. Regarding to parent knowledge/information, vast number of parents of the victim had no information about the working and living conditions of their children trafficked. As the data indicates, more than half $(50.6 \%)$ of the parents reported that they have no knowledge or information about the working condition of their children.

Table 17. Survey children and parents' response on kinds of work conducted by trafficked children.

\begin{tabular}{|c|c|c|c|c|c|}
\hline \multicolumn{6}{|l|}{ Response category } \\
\hline \multicolumn{3}{|l|}{ Children response } & \multicolumn{3}{|l|}{ Parents response } \\
\hline Response & Frequency & Percent & Response & Frequency & Percent \\
\hline Backing injera, & 5 & 5.5 & Preparing coffee, milk & 4 & 4.6 \\
\hline Cleaning house & 19 & 21.1 & Milking (WotetMenat) & 3 & 3.4 \\
\hline Cooking wote & 11 & 12.2 & Baking injera & 4 & 4.6 \\
\hline Washing cooking materials & 14 & 15.5 & Cooking food & 7 & 7.8 \\
\hline Selling Festal & 1 & 1.1 & Keeping shop & 1 & 1.1 \\
\hline House Maids & 9 & 10 & Keeping home & 2 & 2.3 \\
\hline 'koloAzawar' & 8 & 8.9 & & & \\
\hline Selling lottery & 25 & 27.8 & Selling 'kolo' & 1 & 1.1 \\
\hline Washing car & 1 & 1.1 & Selling lottery & 11 & 12.6 \\
\hline Loading ('teshekame) & 9 & 10 & Collecting cotton in farm & 1 & 1.1 \\
\hline Caring children & 8 & 8.9 & Working in restaurants & 3 & 3.4 \\
\hline Daily labour & 8 & 8.9 & Serving as house maids & 4 & 4.6 \\
\hline Beam balance (mizan) & 2 & 2.2 & Caring for children & 3 & 3.4 \\
\hline Working in hotel & 3 & 3.3 & Selling nut (lewuzyazoral) & 1 & 1.1 \\
\hline Begging & 1 & 1.1 & & & \\
\hline Shoe shine & 4 & 4.4 & & & \\
\hline
\end{tabular}

\subsubsection{Repeated Exposure of Children to the Traffickers}

Reports have revealed many cases where the children who have been returned to their communities are soon being subject to re-trafficking. The question also presented for the survey children whether they are trafficked for the second time or not. In this regard, some $(36.7 \%)$ of the interviewed children experienced trafficking before. They also responded the reasons for repeated experience of trafficking. Various reasons mentioned by those who faced trafficking for the $2^{\text {nd }}$ time. These are searching for food access, poor economic condition of their family, bad living condition in rural area, searching for better life in town, peer pressure and brokers (Table 18). 
Table 18. The response of children on repeated exposure for trafficking.

\begin{tabular}{|c|c|c|c|}
\hline Question & Response category & Frequency & Percent \\
\hline \multirow{3}{*}{ Did you have any contact with your parents } & Yes & 53 & 58.9 \\
\hline & No & 37 & 41.1 \\
\hline & Total & 90 & 100 \\
\hline \multirow{3}{*}{ Do have any experience of child trafficking before } & Yes & 33 & 36.7 \\
\hline & No & 57 & 63.3 \\
\hline & Total & 90 & 100.0 \\
\hline
\end{tabular}

Source: Survey result, 2016/17

\subsubsection{Trafficked Children's Response on Their Family's Capacity to Send them School}

As observed in aforementioned result, many children expose to trafficking due to their families' poor economic condition. In this regard, many families have no capacity to afford basic necessities for their children like education, food and clothes. More than half (51.1\%) of trafficked children reported that they exposed to the situation due to lack of families capacity to send them to school (Table 19).

According to the study, out of total interviewed children about $76.6 \%$ dropped education. They forwarded various reasons for dropping of education. Lack of assistance, peer pressure, lack of financial capacity of their families are the main reasons mentioned by trafficked children as a major reasons for dropping education. About $34.4 \%$ and $26.6 \%$ children said that lack of financial capacity of families and no assistance respectively as the major factors for dropping education (Table 19).

Table 19. Interviewed children response on their families' capacity to educate their children.

\begin{tabular}{llll}
\hline Question & Response category & N & \% \\
\hline Family have capacity & Yes & 44 & 48.9 \\
to educate their & No & 46 & 51.1 \\
children & Total & 90 & 100.0 \\
& Yes & 69 & 76.6 \\
Children drop & No & 21 & 23.3 \\
education & Total & 90 & 100 \\
& No willingness & 7 & 7.8 \\
Reasons for dropping & lack assistance & 24 & 26.6 \\
education & Peer pressure & 7 & 7.8 \\
& Lack of financial & 31 & 34.4 \\
& capacity of the family & 69 & 100 \\
\hline
\end{tabular}

Source: Survey result, 2016/17

\subsubsection{Prevalence of Child Trafficking in Local Area}

Both the survey and office data indicate that child trafficking occurring in the study area at alarming rate. The trend of prevalence is increasing from time to time. For instance, D/Fango Women and child affair office registered more than 90 trafficked children cases in 2016/2017. According to the survey data, more than half of interviewed parents said that the prevalence of child trafficking is high (Table 20). Large number of children are exposing to trafficker per annual. In spite of the effort by the office to reduce child trafficking, current trend is much more than the previous time. As evidence indicates, more number of male are exposing to trafficker than female. Most of trafficked children's age rage lies b/n 1213 , according to office report.

Even though there is difference among woredas, the prevalence is high for child trafficking, for example, in Duguna Fangoworeda, the prevalence of child trafficking is getting high. Similarly, in Boloso Bombe, the trend is very high and increasing from time to time because of ginger production failure. The pick season for trafficking children is on Meskelholiday because of peer pressure.

Table 20. Parents response on the prevalence of child trafficking in the study area.

\begin{tabular}{lll}
\hline Response & Frequency & Percent \\
\hline Very High & 24 & 27.6 \\
High & 23 & 26.4 \\
Medium & 20 & 23.0 \\
Low & 18 & 20.7 \\
Very low & 1 & 1.1 \\
No information & 1 & 1.1 \\
Total & 87 & 100.0 \\
\hline
\end{tabular}

Source: Survey result, 2016/17

Trafficked children were asked whether there is any other trafficked children in their family or not. Based on this, about $38.9 \%$ of the survey children reported the existence of other children trafficked from their family (Table 21). Children mentioned various reasons for their exposure to trafficking. These are interest to support their families, poor economic condition of the family, searching for employment and lack of support from family mentioned.

Table 21. Interviewed children response on their families' capacity to educate their children.

\begin{tabular}{llll}
\hline Question & Response category & N & $\mathbf{\%}$ \\
\hline \multirow{3}{*}{$\begin{array}{l}\text { Presence of another trafficked } \\
\text { children in one's family }\end{array}$} & Yes & 35 & 38.9 \\
& No & 55 & 61.1 \\
& Total & 90 & 100 \\
Obtaining advantages from & Yes & & \\
trafficking & No & 23 & 25.6 \\
& Total & 67 & 74.4 \\
\end{tabular}

Source: Survey result, 2016/17

\subsection{Consequences of Child Trafficking}

The data from both the survey and key informant interview depicted that trafficked children are facing many problems/challenges as a result of trafficking. About $67.8 \%$ of the survey children reported that they have faced serious 
challenges during trafficking. Unnecessary punishment, unfair payment, hunger, poor health (sickness) and labour exploitation are some of the negative consequences faced by them. Hunger is the most pronounced problem and reported by $44.6 \%$ of trafficked children (Table 22). Most of the children said that they were not feel free while living with employer. Somme of the negative effect children face from their employer are punishment, fear, rape, biting and insulting. They are also trafficked into variety of exploitative situations including commercial sex, domestic service, service industries like bars and restaurants; begging

According to the survey parents' report children are also facing a serious negative consequences like mental distortion/psychological problem, disease/sickness, no fair payment, developing bad behavior/habit, facing chronic hunger, dropping school, labour exploitation, sleeping under ditch/homelessness. Exposing to disease and chronic hunger are the most serious negative consequences facing them

\section{(Table 23).}

According to the data from Woreda Women and Child affair and police office, various negative consequences faced trafficked children were reported. These are homelessness/sleeping under ditch, living in group, facing disease, physical abuse, losing weight, facing chronic hunger, engaging in begging (brokers use children as tools to generate income), labour exploitation, facing death, no fair payment (even sometimes, they are not getting payment for what they work), dropping education, family always worry for trafficked children, family stranding here and there in search of them, rape, children lack information for their family (Some trafficked children do not know/remember where are their family living) and engaging in prostitution (Table 23).

Even if such a serious child trafficking practice in the study area, there is no intervention designed to support the livelihood of the victims' families and vulnerable children in the area.

Table 22. Children response on challenges they faced during trafficking.

\begin{tabular}{|c|c|c|c|}
\hline Variable & Response category & Frequency $(\mathrm{N}=90)$ & Percent \\
\hline \multirow{3}{*}{ Children have faced challenges during trafficking } & Yes & 61 & 67.8 \\
\hline & No & 29 & 32.2 \\
\hline & Total & 90 & 100.0 \\
\hline \multirow{7}{*}{ Kind of challenges children faced during trafficking } & Unnecessary punishment & 12 & 18.5 \\
\hline & Unfair payment & 10 & 15.4 \\
\hline & Hungry & 29 & 44.6 \\
\hline & Rape & 1 & 1.1 \\
\hline & Stay without any job & 9 & 13.8 \\
\hline & Poor health (sickness) & 11 & 16.9 \\
\hline & Labour exploitation & 17 & 26.2 \\
\hline \multirow{5}{*}{$\begin{array}{l}\text { Negative effects faced children while living with } \\
\text { employer/other family }\end{array}$} & 1. Punishment & 1 & 1.1 \\
\hline & 2. Fear & 7 & 7.8 \\
\hline & 3. raping & 3 & 3.3 \\
\hline & 4. biting & 4 & 4.4 \\
\hline & 5. insulting & 4 & 4.4 \\
\hline \multirow{3}{*}{ Children felt fear when live with another family/place } & Yes & 56 & 62.2 \\
\hline & No & 34 & 37.8 \\
\hline & Total & 90 & 100 \\
\hline \multirow{3}{*}{$\begin{array}{l}\text { Children get access to social services like health and } \\
\text { education after trafficked }\end{array}$} & Yes & 21 & 23.3 \\
\hline & No & 69 & 76.7 \\
\hline & Total & 90 & 100.0 \\
\hline \multirow{3}{*}{ Children sick during trafficking } & Yes & 55 & 61.1 \\
\hline & No & 35 & 38.9 \\
\hline & Total & 90 & 100 \\
\hline \multirow{3}{*}{ Children got treatment on time for sickness } & Yes & 13 & 23.6 \\
\hline & No & 42 & 76.36 \\
\hline & Total & 55 & 100 \\
\hline
\end{tabular}

Source: Survey result, 2016/17

Table 23. Parents response on negative consequences of child trafficking.

\begin{tabular}{lll}
\hline Response & Frequency (N=87) & Percent \\
\hline 1. Exposing to disease/sickness & 25 & 28.7 \\
2. Mental distortion /negative psychological effect & 18 & 20.7 \\
2. Labour exploitation & 35 & 40.2 \\
4. lack of medical treatment & 12 & 13.8 \\
5. No proper/fair payment & 11 & 12.7 \\
6. Developing bad behavior (not obedient for their parents) & 6 & 6.9 \\
7. Chronic Hunger & 28 & 32.2 \\
8. Dropping school/education & 23 & 26.4 \\
9. Punishment & 10 & 11.5 \\
10. Longing for family/family love/Suffering from parents love & 12 & 13.8 \\
11. Feeling lonely & 4 & 4.6 \\
\hline
\end{tabular}




\begin{tabular}{ll}
\hline Response & Frequency (N=87) \\
\hline 12. Coming to home with bare hand (no clothes \& money) & 1 \\
13. Family always worries about trafficked children & 9 \\
14. Homelessness/sleeping under ditch & 1.1 \\
15. Robbed what he/she has & 10.3 \\
16. children given to other person by changing their name and address & 2 \\
17. Expose children to death & 5 \\
18. separate children not to communicate with their parents & 6 \\
19. Lack money for transportation to go back home & 6.5 \\
20. Unemployment & 5.7 \\
21. Making parents lone without support in old age & 6.9 \\
\hline
\end{tabular}

\subsection{Children's Awareness About the Negative Consequences of the Trafficking}

As indicated by survey children, many children had no knowledge about the bad consequences of the trafficking before exposure. This is reported by large number of survey children, which is estimated about $86.7 \%$. On contrary, very few number of trafficked children had information about the negative effects of trafficking prior to exposure. The majority of children have no positive perception towards child trafficking. Large proportion, about $66.7 \%$ of trafficked children perceived child trafficked as bad practice (Table 24). But very small number of them considered child trafficking as a good practice. Further research is required to verify the reasons for those children who reported child trafficking as a good practice.

According to the study, children's negative perception associated with many reasons. According to the result, child trafficking separate/isolate children from their family, expose them to hunger, labor exploitation, family love. Hunger is reported as a major reason. Almost all of the interviewed parents reported that they perceive child trafficking negatively. Some parents have no awareness about the negative consequences of child trafficking, which is reported by $27.6 \%$ of parents' of the victim.

Table 24. Children's response on their Knowledge about trafficking.

\begin{tabular}{|c|c|c|c|}
\hline Variable & Response category & Frequency & Percent \\
\hline \multirow[t]{3}{*}{ Children heard about child trafficking before exposed } & Yes & 12 & 13.3 \\
\hline & No & 78 & 86.7 \\
\hline & Total & 90 & 100.0 \\
\hline \multirow[t]{3}{*}{ Children perception toward child trafficking } & Good & 9 & 10.0 \\
\hline & Bad & 60 & 66.7 \\
\hline & Total & 69 & 76.7 \\
\hline \multirow[t]{2}{*}{ Children have awareness about the presence of legal ground for child trafficking protection } & Yes & 43 & 47.8 \\
\hline & Total & 90 & 100.0 \\
\hline \multirow[t]{3}{*}{ Parents response on understanding/awareness about child trafficking } & Yes & 63 & 72.4 \\
\hline & No & 24 & 27.6 \\
\hline & Total & 87 & 100.0 \\
\hline
\end{tabular}

Source: Survey result, 2016/17. Note: all parents perceive child trafficking negatively

\subsection{Problems Observed at Woreda and Zonal Level in Overcoming Child Trafficking}

According to the office data, there are different activities have been conducted to overcome problem of child trafficking in the study area. Some of the activities done by them are awareness creation towards the negative consequences and protection work. Even though, there are many challenges and gaps reported in avoiding child trafficking. These are:

1. There is no strong child trafficking protection structure at kebele level.

2. Poverty: Inability of family to provide basic necessity for their children

3. Lack of right witness. After taking brokers to person, families says they are sister, brother or the same families living in town. They are taking to send to school.

4. Lack of temporary staying place for children (no provision of food for time being)

\section{Challenges for legal enforcement of child trafficking}

While bringing child trafficking case to the court, parents are not cooperating for legal implementation by telling wrong information. In some cases, after capturing the children and bring to the court to identify and punish brokers, parents are saying that" he/she is my relative and I'm voluntarily giving my child to him/her so that my child will attend education in better way.

Again, because the brokers give bribes to the people and in some case also to some government officials, appropriate implementation of the legal framework for this regard is challenging. In addition, long appointment to give decision in the court and staying the trafficked children in police station is creating a burden for police officers economically and institutionally so that they free victims and parents sometimes. There is no room for children in all police stations and these trafficked children were staying with adults this is a main challenge. No budget to facilitate food for children when trafficked children stay at police station until 
their case was processed in court is also another burden for police officers economically.

Recently, the court case of child trafficking was taken to High court and transporting witnesses and children from Woreda still need additional budget and become another challenge.

a. According to Women and child Affair Office, there is no appropriate punishment for brokers. For example, in Duguna Fango one broker jailed for 3 years for red caped when trafficking 8 children from local area. There is problem in legal process. Judgment handled by traditional process. No appropriate punishment given in the way compensating children's suffering. Judge is corrupted (they are cheat by money).

b. Children not giving right witness. After catching/controlling brokers, Children say we are going to town by ourselves.

c. As reported police office, the number of year for judgment for trafficker15 (minimum jail year). But still not put into practice/no implementation. No fair judgment. Family cheat by local people, they not accuse them. They solve the issue traditionally.

\section{Conclusion and Policy Implication}

\subsection{Conclusion}

The practice of child trafficking is one of the most challenging problems and, it is happing at alarming rate in study area. It is a crime that deprives children's human rights and freedoms, increases health risks. The consequences of child trafficking are devastating. It leads trafficked children suffering from physical, mental and emotional abuse, labour exploitation, hunger, disease, rape, threats against self and family, and even death. It is one of the major social problems facing community and children in the study area.

According to the finding, main cause of child trafficking is to a large extent poverty (poor economic condition of the family), peer pressure and lack of opportunity which force significant number of children to look for a better life by moving away from the places they call home. Child trafficking is a serious crime that many governments, nongovernmental organizations and community-based organizations at national and zonal level are trying to address.

As the study reveals the prevalence of child trafficking is increasing from time to time at substantial rate in the study area. At the current time the situation is beyond the capacity to manage by governmental and non-governmental organizations, who are engaged on fighting the violence against child life. Many negative consequences have been seen on children due to child trafficking. However, parents of trafficked children are under false illusions and are unaware of the severe exploitation to which their children are often subjected.

Trafficked children engage in various activities such as selling lottery, house maids, domestic work and agriculture, all of which expose them to risks. Children aged between 8 and 17 are the most preferred by traffickers because of their cheap labour potential.

Children are forced to expose to trafficking due to a combination of push and pull factors, including misconception regarding life in urban centers. These children come to the cities/town with the traffickers by promises of good education or employment but end up as, sex workers, domestic workers, or left on the street without food, shelter, clothing or any protection.

According to this study, socio-economic conditions of the families of trafficked children is not worthy to sustain families life. Farm size is very small and which may not enable to support livelihood in long run. Majority of parents of trafficked children engaged in non and off-farm activities which are pursued for the sake of survival issue rather than investment. They possess very meager livelihood assets such as small land size, livestock and many of them have no oxen which is basic economic asset for household.

\subsection{Policy Implication}

Based on the findings of the study, the following policy recommendations are possible areas of intervention which might help to adopt best alternative mechanisms to overcome the problem in the study area.

a. Farm land, the basic livelihood asset of farm households, is very small and is not in position to enable families of trafficked children to generate adequate income and access to food in sustainable way. Therefore, the livelihood improvement of victims' families and vulnerable children should focus on alternative income generating activities like production of small ruminant, poultry, vegetable production, etc. Creating new employment opportunities for wage laborer is one of the important policy implications.

b. Large number of families of trafficked children engaged in non-farm and off-farm activities beside agriculture. Therefore, strengthening and improving best practice among them, building the capacity of unskilled labor to up-grade their knowledge/experience to contribute their labour in non-agricultural sectors, creating the employment opportunities for wage labours are the most important policy directions.

c. Poor economic condition (poverty) of the families of trafficked children is a principal factor leading/exposing children for trafficking. The supports to victims is a critical element in the fight against trafficking. Therefore, direct involvement of different stakeholders like NGOs in assisting children and families of the victims is unprecedented issues. In this regard, building the livelihood of the victims' families and vulnerable families is important. Supporting children to continue education by providing learning material, food, clothes and medical service also can play great role in reducing the incidence of trafficking. This should be done by identifying the children living with extreme poverty from the local area and at school level. 
d. Peer pressure/friends plays very significant role in exposing children to the hands of cruel traffickers. Thus, strong and regular awareness creation work should be done for local community, families and children about the negative consequences of child trafficking.

e. Strong child trafficking protection structure by police office should be extended up to kebele level.

f. Setting special child trafficking protection committees at local/kebele level; and strengthening this committee by assigning recruited personnel can be the important solutions for the existing problem. This committee can make regular follow up at kebele level (to work at church, school, village) in collaboration with Woman and child affair and police office.

g. Developing self help organizations in local area can be an importance mechanism to support vulnerable families and child school drop. This organization can facilitate fund raising activities from local people in volunteer base (either cash or kind). It is better, if those who have capacity (financial capacity or living in better wealth status) supporting those who have no capacity to fulfill food, clothes and exercise book for their children. Volunteer can collect either grain or cash, then keeping grain in store and saving cash until need rises.

h. The study also pointed out changing the legal procedure of the judgment. Especially, in the case of child trafficking, it is better if giving very limited chance for traditional judge. There should have consistent judgment throughout the woredas to punish those who are violating the rule.

i. There is no rule of accusing or punishing drivers $b / c$ of transporting trafficked children. It is better, if there is legal ground to make drivers responsible when they transport children without family permission to somewhere.

j. Separate room has to be either build or reserved at police station to stay children. This can enable to give temporary child care, screening and receiving witness, collect concrete/empirical evidence to punish broker, verifying/getting information on how trafficking process is done and integrating the children with their family.

$\mathrm{k}$. Budget has to be allocated for police stations to accommodate trafficked children and other people in relation to that.

1. After controlling trafficked children, family/local people do not want to give any information/evidence about brokers for official case, they try to mask the secret. Rather than this they say a person who engaged trafficking as their family (brother, sister, relatives). Hence, legal and moral responsibility awareness has to be created for a wider community through Kebele and woreda administrators.

m.In order to strengthen the protection in sustainable way, child caring program should be supported with regular budget in Women and Child Affair office.

n. Traffickers use different direction to transport trafficked children, so police and community should work together in order to prevent the process.

o. The concerned bodies should take care when giving support letter to permit family sending their children for relatives in the town or other places. Strong regulation should be set in this regard.

p. Protection work at bus station level is very weak. Therefore, it should be strengthen by working in collaboration with other concerned bodies/stakeholders.

q. Child trafficking tackling intervention needs involvement of multiple stakeholders. Hence, concerned stakeholders collaboration has to be strengthened.

\section{References}

[1] Kumar A.P. Senthil, 2015. Mysery and Myopia: Child Trafficking is a Channel to Worst Forms of Child Labour in Ethiopia, vol. 4, March, 2015.

[2] Saad Suhana and Salman Ali, 2014. Government policy and the challenge of eradicating human trafficking in Malaysia, Malaysian Journal of Society and Space 10 issue 6 (66-74) 66 (C), ISSN 2180-2491.

[3] Goel, V, 2009. Children's human rights in underdeveloped country: A study in Ethiopian perspective. African Journal of Political Science and International Relations, Vol. 3 (4), pp. 142-155.

[4] Miller-Perrin C.L. \& Perrin, R.D. 2007. Child maltreatment: An introduction, 2nd ed. Thousand Oaks, CA: Sage.

[5] Eileen, M, 2008. Effective Child Protection. 2nd ed. Sage Publications Ltd.

[6] Ike A. Chris \& Twumasi-Ankrah K, 1999. Child Abuse and Child Labour Across Culture: Implications for Research, Prevention and Policy Implementation. Journal of Social Development in Africa, 14, 2,109-118

[7] Genaye, E, 2008. Effectiveness of "Children"s Right Pictorial Booklet" in Awareness Creation of Children on Child Rights, (Unpublished MA Thesis), Addis Ababa University, Addis Ababa.

[8] Maheder B, 2008. Child Abuse and Neglect and Alternative Policy Solutions. Dr Deborah Zinn, Dr Richard Kordesh, Dr Alice Butterfield Johnson, Ato Zena Berhanu (Eds.), Ethiopian Social Policy Reader, Vol. 1. Addis Ababa University.

[9] Belay, H, 2007.Abuse \& Neglect: Experiences of Orphan \& Vulnerable Children in Addis Ababa. Proceedings of the 6th National Conference of the Ethiopian Psychologists Association, Addis Ababa.

[10] Getnet, T, 2001. Obstacles, controversies and prospects surrounding child abuse management in Addis Ababa. Northeast African Studies, Vol 8 (1), 115-141.

[11] Redlinger, J., 2004. Child trafficking and sexual exploitation. United States of America: | University of Iowa.

[12] Atsedewoine Tekle and TsehayBelaynehe,2000. Trafficking of Women from Ethiopia.

[13] ILO, 2002. A report on Trafficking and Sexual Abuse among Street Children in Katmandu, Nepal. 
[14] Njuguna Wambui, 2010. Child Trafficking in Eastern Africa Region. A Regional Effort to Protect the Vulnerable Presented to The Senior Officials Meeting on Migration, Mobility and Employment Brussels, Belgium 15 - 17 September, 2010.

[15] Save the children, 2003. Child Labor in Ethiopia with special focus on Child Prostitution. This study was jointly carried with Addis Ababa City Administration Social and NGO Affairs Office- SNGOA, Save the Children Denmark (SCD) and African Network for the Prevention of and Protection Against Child Abuse and Neglect-Ethiopia Chapter (ANPPCAN), Addis Ababa.

[16] WZWCAO, 2014.Wolaita zone women and child affair office report, 2014.

[17] CSA. 2010. Population and housing census of Ethiopia. Results for Country level statistical report, A.A. July 2010: http://www.csa.org.

[18] WZFEDD. 2012. Wolaita Zone socio-economic information. Wolaita Zone Finance and Economic Development Department, May 2012.
[19] CSA. 2007. Population and housing census of Ethiopia, A.A.

[20] Ghosh, J. and Bharadwaj, K.1992. 'Poverty and Employment in India', in H. Bernstein, B. Crow and H. Johnson (eds) Rural Livelihoods: Crises and Responses, Oxford: Oxford University Press and The Open University.

[21] Mujib Urrehman, J. and Rana, M. F. 2008. Five livelihood strategies of different categories of households in rural areas of Abbottabad, Pakistan. Sarhad J. Agric. Vol.24, No.4, 2008.

[22] Babatunde, R. O., Olagunju, F. I., Fakayode, S. B. and Adejobi, A.O. 2010. Determinants of participation in off-farm employment among small-holder farming households in Kwara State, Nigeria

[23] Berry, S. 1989. Coping with Confusion: African farmers' responses to economic instability in the 1970s and 1980s, Boston: African Studies Centre, Boston University. 